\title{
Mineral balance in infantile cortical hyperostosis: effects of corticosteroids
}

\author{
D G D Barr, N R Belton
}

\begin{abstract}
The effects on mineral metabolism of therapeutic doses of corticosteroids were investigated in infantile cortical hyperostosis; in four untreated cases the calcium, phosphorus, and magnesium balances were strongly positive. In one severe case, treatment with prednisolone was associated with an alteration to negative calcium and magnesium balance, and faecal losses of calcium were particularly high. This effect persisted for at least three months after the steroids had been discontinued, and during this period there was pronounced retardation of linear growth. Six months after the treatment had been stopped mineral balance was again positive and there was rapid 'catch up' in growth.

In infancy, the negative effect of corticosteroids on calcium, phosphorus, and magnesium metabolism may contribute to inhibition of bone growth and steroid stunting.
\end{abstract}

We know of few biochemical studies in infantile cortical hyperostosis. Serum calcium and phosphorus concentrations are normal but alkaline phosphatase activity is usually increased during the active phase. ${ }^{1}$ Aminoaciduria has been reported in one case. ${ }^{2}$

Corticosteroid treatment has been advised with reservation ${ }^{34}$ but recommended for all patients, ${ }^{15}$ particularly for severe cases. ${ }^{6}$ In this study of infantile cortical hyperostosis one case, whose growth was studied longitudinally, had a series of balance studies for calcium, phosphorus, and magnesium before, during, and after treatment with corticosteroids. Three other cases not receiving steroids had single balance studies.
Patients and methods

Clinical details of the four infants are shown in table 1. Case 1 had generalised disease and was seriously ill; a protracted course of corticosteroid was therefore necessary. Case 2 had generalised disease, and cases 3 and 4 had disease localised to the mandible that resolved without the need for steroids.

Balance studies, except where stated, all extended over five day periods. Analysis for calcium, phosphate, and magnesium was made on duplicate diets, stools, and urine. Samples were homogenised and aliquots were digested in dilute nitric acid. Calcium and magnesium were estimated by atomic absorption spectrophotometry and phosphate by a micro adaptation of the phosphomolybdate method of Fiske and Subbarow?

\section{Results}

In all four patients serum calcium, magnesium, and phosphorus were always within normal limits and there was no evidence of acid-base disturbance, hepatic, renal glomerular, or tubular dysfunction.

Changes in linear growth in case 1 are shown in fig 1. Height is shown as the difference between the observed value and the normal mean height for that age expressed as a proportion of the normal SD for that age (SD score). Balance data in the four cases are shown for calcium, phosphorus, and magnesium in tables 1 , 2 , and 3 , respectively. Sequential balance data for case 1 are shown diagrammatically in fig 2 .

When untreated (case 1, balance (i); cases 2, 3 , and 4) gross retention of calcium was high for age and also in relation to intake. ${ }^{89}$ This excessive retention was especially pronounced in
Royal Hospital for Sick Children, Edinburgh D G D Barr

Department of Child Life and Health, University of Edinburgh, 17 Hatton Place, Edinburgh EH9 1UW N R Belton Correspondence to: Dr Belton.

Accepted 19 July 1990

Table 1 Calcium balances

\begin{tabular}{|c|c|c|c|c|c|c|c|}
\hline & \multirow{2}{*}{$\begin{array}{l}\text { Age } \\
\text { (months) }\end{array}$} & \multirow{2}{*}{$\begin{array}{l}\text { Weight } \\
(\mathrm{kg})\end{array}$} & \multirow{2}{*}{$\begin{array}{l}\text { Intake } \\
\text { (mmol/day) }\end{array}$} & \multicolumn{2}{|c|}{ Output (mmol/day) } & \multirow{2}{*}{$\begin{array}{l}\text { Gross } \\
\text { retention } \\
\text { (mmol/day) }\end{array}$} & \multirow[t]{2}{*}{ Comment } \\
\hline & & & & Faeces & Urine & & \\
\hline $\begin{array}{l}\text { Case 1: } \\
\quad \text { Balance (i) }\end{array}$ & $3 \cdot 5$ & $4 \cdot 9$ & $28 \cdot 7$ & $18 \cdot 6$ & 0.6 & $9 \cdot 5$ & $\begin{array}{l}\text { Clinical onset aged } 10 \text { weeks } \\
\text { Generalised disease } \\
\text { One week before steroids started }\end{array}$ \\
\hline $\begin{array}{l}\text { Balance (ii) } \\
\text { Balance (iii)* }\end{array}$ & $\begin{array}{l}5 \\
6 \cdot 5\end{array}$ & $\begin{array}{l}5 \cdot 1 \\
5 \cdot 9\end{array}$ & $\begin{array}{l}24 \cdot 0 \\
18 \cdot 7\end{array}$ & $\begin{array}{l}20 \cdot 95 \\
18 \cdot 5\end{array}$ & $\begin{array}{l}0 \cdot 2 \\
0 \cdot 7\end{array}$ & $\begin{array}{l}2 \cdot 85 \\
-0 \cdot 5\end{array}$ & $\begin{array}{l}\text { Prednisolone } 10 \mathrm{mg} / \text { day for one month } \\
\text { Prednisolone } 10 \mathrm{mg} / \text { day for two months } \\
\text { Off steroids for two weeks } \\
\text { ACTH } 20 \mathrm{IU} \text { daily in week } 1 \text {, three times in } \\
\text { week } 2 \text {, and twice in week } 3\end{array}$ \\
\hline $\begin{array}{l}\text { Balance (iv) } \\
\text { Balance (v) } \\
\text { Case } 2\end{array}$ & $\begin{array}{c}10 \\
14 \\
4 \cdot 5\end{array}$ & $\begin{array}{l}7 \cdot 1 \\
8 \cdot 7 \\
5 \cdot 9\end{array}$ & $\begin{array}{r}8 \cdot 4 \\
11 \cdot 1 \\
19 \cdot 0\end{array}$ & $\begin{array}{l}8 \cdot 7 \\
5 \cdot 2 \\
9 \cdot 1\end{array}$ & $\begin{array}{l}0 \cdot 4 \\
0 \cdot 1 \\
0\end{array}$ & $\begin{array}{r}-0 \cdot 7 \\
5 \cdot 8 \\
9 \cdot 9\end{array}$ & $\begin{array}{l}\text { Off treatment for three months } \\
\text { Six months after end of steroid treatment } \\
\text { Clinical onset aged } 9 \text { weeks } \\
\text { Generalised disease; relapse at age } 4 \text { months }\end{array}$ \\
\hline Case 3 & 4 & $6 \cdot 8$ & $21 \cdot 5$ & $12 \cdot 2$ & 0.9 & $8 \cdot 4$ & $\begin{array}{l}\text { Clinical onset aged } 11 \text { weeks } \\
\text { Localised disease }\end{array}$ \\
\hline Case 4 & 5 & $5 \cdot 6$ & $17 \cdot 7$ & $10 \cdot 0$ & $1 \cdot 4$ & $6 \cdot 3$ & $\begin{array}{l}\text { Clinical onset aged } 4 \text { months } \\
\text { Localised disease }\end{array}$ \\
\hline
\end{tabular}




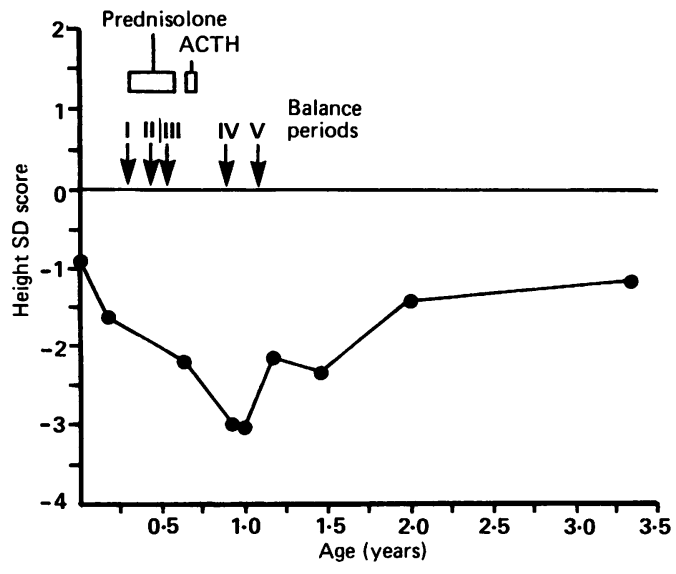

Figure 1 Changes in linear growth in case 1 in relation to balance periods and treatment. (ACTH, adrenocorticotrophic hormone.)

Table 2 Phosphorus balances

\begin{tabular}{|c|c|c|c|c|}
\hline & \multirow{2}{*}{$\begin{array}{l}\text { Intake } \\
\text { (mmol/day) }\end{array}$} & \multicolumn{2}{|c|}{ Output (mmol/day) } & \multirow{2}{*}{$\begin{array}{l}\text { Gross } \\
\text { retention } \\
\text { (mmollday) }\end{array}$} \\
\hline & & Faeces & Urine & \\
\hline $\begin{array}{l}\text { Case 1: } \\
\text { Balance (i) } \\
\text { Balance (ii) } \\
\text { Balance (iii)* } \\
\text { Balance (iv) } \\
\text { Balance (v) } \\
\text { Case 2 } \\
\text { Case } 3 \\
\text { Case 4 }\end{array}$ & $\begin{array}{l}29 \cdot 5 \\
19 \cdot 2 \\
21 \cdot 4 \\
12 \cdot 5 \\
20 \cdot 6 \\
19 \cdot 5 \\
27 \cdot 7 \\
21 \cdot 0\end{array}$ & $\begin{array}{r}15 \cdot 2 \\
14 \cdot 7 \\
11 \cdot 6 \\
4 \cdot 4 \\
5 \cdot 2 \\
5.9 \\
17 \cdot 4 \\
11 \cdot 4\end{array}$ & $\begin{array}{l}6 \cdot 7 \\
3 \cdot 9 \\
2 \cdot 9 \\
6 \cdot 0 \\
5 \cdot 4 \\
7 \cdot 8 \\
8 \cdot 1 \\
7 \cdot 6\end{array}$ & $\begin{array}{r}7.6 \\
0.6 \\
6.9 \\
2.1 \\
10 \cdot 0 \\
5.8 \\
2.2 \\
2.0\end{array}$ \\
\hline
\end{tabular}

*Three day balance period, all others five day periods.

Table 3 Magnesium balances

\begin{tabular}{lllll}
\hline & $\begin{array}{l}\text { Intake } \\
\text { (mmol/day) }\end{array}$ & \multicolumn{2}{l}{ Output (mmol/day) } & $\begin{array}{l}\text { Gross } \\
\text { retention } \\
\text { (mmol/day) }\end{array}$ \\
\cline { 3 - 5 } & & Faeces & Urine & \\
\hline Case 1: & & & & \\
Balance (i) & 4.2 & 2.9 & 0.3 & $1 \cdot 0$ \\
Balance (ii) & 4.4 & 3.6 & 0.1 & 0.7 \\
Balance (iii) & 4.2 & 3.9 & $0 \cdot 1$ & $0 \cdot 2$ \\
Balance (iv) & 2.6 & 1.9 & 0.8 & -0.1 \\
Balance (v) & 3.9 & 2.0 & 0.8 & $1 \cdot 1$ \\
Case 2 & 3.1 & 1.5 & $0 \cdot 2$ & 1.4 \\
Case 3 & 2.8 & 2.2 & 0.2 & 0.4 \\
Case 4 & 2.9 & 1.9 & 0.4 & 0.6 \\
\hline
\end{tabular}

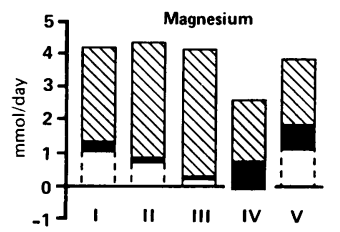

Figure 2 Sequential mean 24 hour mineral balances in case 1. Intake is shown by the upper limit of the enclosed block from the base line. Excretion is represented by the distance between the upper and lower limits of the enclosed block. Urinary excretion is represented by the solid shading of the enclosed block, and faecal excretion is shown by the diagonal shaded portion of the enclosed block. Mineral balance is thus the distance between the lower limit of the enclosed block and the base line and is positive when the lower limit of the enclosed block is above the line and negative when it is below.
*Three day balance period, all others five day periods.

cases 1 and 2 who had widespread disease. Gross retention of phosphate was high in case 1, but near normal for age and intake in the other to calcium retention. Gross retention of magnesium was high in cases 1 and 2, and normal in cases 3 and 4 .

The effect of treatment with corticosteroids was shown in case 1. After one month, gross retention of calcium had fallen to one third of the presteroid value, mainly because of an absolute and proportional rise in faecal calcium. The change became more pronounced (balance (iii)), creating negative balance that progressed after steroids had been discontinued until balance (iv) when, three months after stopping treatment, faecal calcium was greater than calcium intake and pronounced negative balance resulted. Six months after corticosteroids had been stopped the calcium balance was again strongly positive. cases. ${ }^{89}$ Phosphate retention was low in relation
Changes in phosphate balance were less pronounced and consistent, but magnesium retention fell progressively and balance became negative at the time when calcium retention was lowest. Urinary magnesium seemed to rise at this stage, although in magnesium deprivation there is usually renal conservation. ${ }^{10}$

\section{Discussion}

The metabolic balance data presented here show that untreated infants with cortical hyperostosis are in strongly positive mineral balance.

Balance is usually positive in infancy with a net retention of calcium of about $5 \mathrm{mmol}(200$ $\mathrm{mg}$ )/day to allow for accretion into the growing skeleton. ${ }^{8}$ Anything less than this implies a net deficit of calcium, and balances that actually become negative (case 1 balances (iii) and (iv) indicate a serious degree of mineral depletion.

The general tendency to positive balance in cases 2, 3, and 4-and in case 1 the strongly positive balance before and after treatmentsuggest that corticosteroids were indeed responsible for the change to negative mineral balance that occurred in case 1 .

The main reason for this negative calcium balance seemed to be an increase in faecal losses. This effect persisted for months after treatment had been stopped, suggesting some profound functional alteration in intestinal mechanisms of absorption or excretion. The tendency for faecal calcium to exceed calcium intake might indicate a state of calcium leakage into bowel ('calcium losing enteropathy').

Urinary calcium in cases 1,3 , and 4 was within the reference range, ${ }^{8}$ but in case 2 no calcium was detected in the urine over a five day period, and at other times values of $0.025 \mathrm{mmol}$ and $0.15 \mathrm{mmol} /$ day were obtained. In this case serum calcium tended to be near the lower limit of the reference range; as a result tubular reabsorption of calcium may have been enhanced by the effect of secondary hyperparathyroidism. The aminoaciduria reported in Caffey's disease by Campbell and Turner was renal in type, also suggesting an effect on tubular function. ${ }^{2}$

The relationship between the changes in mineral balance and the growth retardation in case 1 is uncertain, as the effects of treatment cannot be entirely separated from the effects of the disease. Negative balance coincided with maximum depression of linear growth, however, and a reversion to positive balance correlated with the period of 'catch up' growth. Prolonged courses of large doses of corticosteroids lead to stunting with impairment of bone growth and delayed skeletal maturation, ${ }^{11}{ }^{12}$ but the pathogenesis of these effects remains uncertain. ${ }^{13} 14$ Among contributing factors, the adverse effects of corticosteroids on mineral metabolism and bone have been shown in children, ${ }^{15-17}$ and direct correlation shown between the degree of osteopenia and the extent of growth retardation. ${ }^{18}$ The reported effects of corticosteroids on bone include inhibition of collagen synthesis, ${ }^{14}$ decreased osteoblastic activity, ${ }^{19}$ and osteopenia. ${ }^{17} 1820$

Calcium depletion complicating treatment with steroids in children has been 
described. ${ }^{15} 16$ Inhibition of intestinal calcium transport, ${ }^{21}$ calciuria, ${ }^{22}$ reduced production of 1,25 dihydroxyvitamin $\mathrm{D},{ }^{23}{ }^{24}$ depletion of circulating 25 -hydroxyvitamin $\mathrm{D},{ }^{25}$ or antagonism to the effects of vitamin $D,,^{26}$ have all been implicated. Vitamin D seemed to enhance catch up growth after courses of steroids in rats treated with cortisone. ${ }^{28}$

During rapid development of the skeleton in infancy, the side effects of steroids on linear growth and mineral metabolism might be especially undesirable.

This study suggests that mineral depletion by corticosteroids may be severe and prolonged in infancy contributing to the inhibition of bone growth. Mineral supplements, with or without vitamin $\mathrm{D}$, might help to offset these mineral losses and mitigate the stunting effects of steroids.

1 Caffey J. Pediatric X-ray diagnosis. 5th Ed. Chicago: Year Book Publishers, 1967:961-73.

2 Campbell DJ, Turner EJ. Aminoaciduria in a case of infantile cortical hyperostosis. Am f Clin Pathol 1962;38:397-400. Gellis SS. Editorial comment in: Year book of pediatrics, 1957 58 series. Chicago: Year Book Publishers, 1957:341.

4 Pickering D, Cuddigan B. Infantile cortical hyperostosis associated with thrombocythaemia. Lancet 1969;ii:464-5.

5 Holman GH. Infantile cortical hyperostosis-a review. Quarterly Review of Pediatrics 1962;17:24.

terly Review of Pediatrics 1962;17:24.
6 Silverman FN. Infantile cortical hyperostosis. In: Silverman FN, ed. Caffey's pediatric $x$-ray diagnosis. 8th Ed. Chicago: FN, ed. Caffey's pediatric x-ray diagn

7 Fiske CH, Subbarow Y. The colorimetric determination of phosphorus. F Biol Chem 1925;66:375-400.

8 Kahn B, Straub CP, Robbins PJ, Wellman HN, Seltzer RA, Telles NC. Retention of radiostrontium, strontium, calcium and phosphorus by infants. Pediatrics 1969;43: 651-756.

9 Fomon SJ, Owen GM, Jensen RL, Thomas LN. Calcium and phosphorus balance studies with normal full term fed pooled human milk or various formulas. Am $\mathcal{f}$ Clin Nutr 1963;12:346-57.

10 Walker WEC, Parisi AF. Magnesium metabolism. $N$ Engl F Med 1968:278:658-63.

11 Blodgett FM, Burgin L, Iezzoni D, Gribetz D, Talbot NB. Effects of prolonged cortisone treatment on the statural growth, skeletal maturation and metabolic status of chilgrowth, skeletal maturation and metabolic
dren. N Engl f Med 1956;254:636-41.
12 Morris HG. Growth and skeletal maturation in asthmatic children: effect of corticosteroid treatment. Pediatr Res 1975;9:579-83.

13 Anonymous. Corticosteroid therapy and growth. (Editorial.) $B M F$ 1969;i:393-4

14 Hyams JS, Carey DE. Corticosteroids and growth. Pediatrics 1988;113:249-54.

15 Manson G, Johnston JA. Studies in rheumatic fever IV Attempts to offset the calcium losses incidental to steroid Attempts to offset the calcium losses incident

16 Jones JH, Peters DK, Morgan DB, Coles GA, Mallick NP. Observations on calcium metabolism in the nephrotic synObservations on calcium metabolism

17 Chesney RW, Mazess RB, Rose P. Bone mineral status measured by direct absorptiometry in childhood renal disease. Pediatrics 1977;60:864-72.

18 Chesney RW, Mazess RB, Rose P, Jax DK. Effect of prednisone on growth and bone mineral content in childhood glomerular disease. Am $\mathcal{7}$ Dis Child 1978;132:768-72.

19 Peck WA, Brandt J, Miller I. Hydrocortisone-induced inhibition of protein synthesis and uridine incorporation in isolatated bone cells in vitro. Proc Natl Acad Sci USA 1967;57:1599-606.

20 Saville PD, Karmosh O. Osteoporosis of rheumatoid arthritis: influence of age, sex and corticosteroids. Arthritis Rheum 1967;10:423-30.

21 Kimberg DV, Baerg RD, Gershon E, Graudusius RT. Effect of cortisone treatment on the active transport of calcium by the small intestine. $\mathcal{F}$ Clin Invest 1971;50:1309-21.

22 Suzuki Y, Ichikawa Y, Saito E, Homma M. Importance of increased urinary excretion in the development of secondary hyperparathyroidism of patients under glucocorticoid therapy. Metabolism 1983;32:151-6.

23 Chesney RW, Hamstra AJ, Mazess RB, De Luca HF, O'Reagan S. Reduction of serum 1,25-dehyroxyvitamin D in children receiving glucocorticoids. Lancet 1978;ii: 1123-5.

24 O'Regan S, Chesney RW, Hamstra AJ, Eisman JE, O'Gorman AH, De Luca HF. Reduced serum 1,25(OH) vitamin $\mathrm{D}_{3}$ levels in prednisone-treated adolescents with systemic lupus erythematous. Acta Paediatr Scand 1979;68: 109-11.

25 Klein RG, Arnaud SB, Gallagher JC, De Luca HF, Riggs BL. Intestinal calcium absorption in exogenous hypercortiBL. Intestinal calcium absorption in exogenous hypercortisonism. Role of 25-hydroxyvitamin

26 Seeman E, Kumar R, Hunder GG, Scott M, Heath H III, Riggs BL. Production, degradation and circulating levels of 1,25-dihydroxyvitamin $\mathrm{D}$ in health and in glucocorticoid excess. F Clin Invest 1980;66:664-9.

27 Rickers H, Deding A, Christiansen C, Rodbro P, Nestoft J. Corticosteroid-induced osteopenia and vitamin $D$ metabolism. Effect of vitamin $D_{2}$, calcium phosphate and sodium fluoride administration. In: Norman AW, Schaefer $\mathbf{K}$, Herrath DV, Grigoleit H-G, eds. Vitamin D: chemical, biochemical and clinical endocrinology of calcium metabolism. Berlin: Walter de Gruyter, 1982:1027-9.

28 Mitchell I, Barr DGD, Pocock SJ. Catch-up growth in cortisone-treated rats: effects of calcium and vitamin D. Pediatr Res 1978;12:1105-11. 